\title{
TWO NEW ACAROFAUNA INHABITING SOME FRUIT TREES IN NORTH SINAI, EGYPT (ACARI: CHEYLETIDAE \& TYDEIDAE)
}

\author{
Eman A.I. Ali ${ }^{* 1}$, M.M.H. Kandeel ${ }^{2}$, S.M. Abd-ElKaream ${ }^{1}$ \\ and M.N. El-Bassiony ${ }^{1}$ \\ 1. Dept. Pant Prod., Fac. Environ. Agric. Sci., Arish Univ., Egypt. \\ 2. Fac. Tech. Dev., Zagazig Univ., Egypt.
}

\begin{abstract}
Two new species of mites are Cheletomimussinaiin. sp. (Prostigmata: Cheyletidae) and Paralorryiaegyptocitri n. sp. (Prostigmata: Tydeidae) are illustrated and described. Both the new species inhabit some fruit trees in North Sinai, Egypt.
\end{abstract}

Key words: Description, new species, Cheletomimussinaiin.sp., Paralorryiaegyptocitri n. sp.

\section{INTRODUCTION}

Members of family Cheyletidae are often abundant in granaries, animal feed warehouses barns, and stables, especially if acarid populations are high. They are found also in leaf litter and topsoil wherever conditions support a substantial soil fauna. Some occur on the bark and foliage of fruit trees and other woody plants where they may feed on scale insects and plant- feeding mites (Summers and Price, 1970). Oudemans $\left(\mathbf{1 9 0 4}^{\text {b }}\right)$ created the genus Cheletomimusto include only one species Cheletomimusberlesei. Yunker (1961) described Cheletomimusdenmarki, (Muma, 1964) erected Cheletomimusduoselosus from sand pine litter, and pointed to $C$. berlesei and $C$. denmarki. Summers and Price (1970) recorded $C$. berlesei and $C$. duoselosus. Soliman (1975) erected Cheletomimus minutes. Negmand Mesbah (2014) aggregated the cheyletid mites of Egypt.

They mentioned that Hemicheyletiabakeri Al-Youssif \& Soliman is Cheletomimusbakeri (Ehara) and HemicheyletiacongensisZaher is Cheletomimuscongensis (Cunliffe). Species of family Tydeidae inhabit the

\footnotetext{
* Corresponding author: Tel.: +201011915154

E-mail address: emanabdalla107@gmail.com
}

organic strata of soil, lichens, mosses, trees and shrubs and are considered to be fungivorous and predacious mites (Marshall, 1970; Hessein and Perring, 1986; Momen, 1986). Baker $\left(\mathbf{1 9 6 8}^{\mathrm{b}}\right)$ reviewed the genus Paralorryia and described 14 new species belonging to the genus. In addition he gave a key for the already known species along with the new taxa. Gerson (1968) described Paralorryianesziyyonensis and recorded Paralorryiamali (Oudemans). Rasmy and El-Bagoury (1980) described Paralorryiaaegyptiaca. Zaher and El-Bagoury (1981) described Paralorryiabakeri.

\section{MATERIALS AND METHODS}

The new taxa were collecting inhabiting some fruit trees in the two districts, ElArish and Beer El-Abd, North Sinai. The two new species Cheletomimussinaii n. sp. and Paralorryiaegyptocitri n. sp. were mounted in Hoyer's modification ofchloral hydrate preservative on microscope slides. The new taxa were collecting inhabiting some fruit trees in the two districts, ELArish and Beer El- Abd, North Sinai. 
The two new species Cheletomimussinaiin. sp. and Paralorryiaegyptocitri $\mathrm{n}$. sp. were mounted in Hoyer's modification of chloral hydrate preservative on microscope slides. The two new species were illustrated using a drawing eye piece under the high magnification of $10 \times 100$ using oil immersion. They were examined with phase contrast illumination at magnifications varying from $125 \times$ too $500 \times$. Measurements were made at $125 \times$ and adjusted to nearest $0.01 \mu$. Description refer only to females, males were not captured.

\section{RESULTS AND DISCUSSION}

\section{Genus Cheletomimus Oudemans}

Cheletomimus Oudemans, 1904b, Ent. Ber. Nederl. Ent. Ver. 1(18):163.

\section{Diagnosis}

Adult female with three dorsal shields, one propodosomal and twohysterosomal. Median dorsal setae of idiosoma similar to laterals in from and size. There are two comb-like and two sickle-like setae on palpal tarsus and the palpal claw is toothed. The first pair of legs bear two tarsal claws and a pulvillus. Eyes present.

\section{Type species}

Cheyletusberlesei (Oud, 1904 ${ }^{\mathrm{a}}$ ), Ent. Ber. Nederl. Ent. Ver.1 (17): 154. Cheletominussinaiin. sp. (Figs. 1-3)

Diagnosis: The most distinctive diagnostic character of this new species is the last dorsal pair of setae arise on tubercles and incommodiously than other dorsals, but longer than them; the presence of punctuation, ornamentation and striae on the dorsal shields are obvious than those on the other three known species $C$. berlesei, $C$. minutes Soliman and $C$. duoselosus Muma.

\section{Female:}

Body length including rostrum $261 \mu$; width $182 \mu$; rostrum $60 \mu$. Rostral shield granulate except on the posterior third, finely doted. Terminal setae situated on short lateral tubercles near apex. Body alutaceous with obvious dorsal shields; propodosomal shield trapezoidal, invaded by the eyes on the anterio-lateral margins, provided with four pairs of lance-like pilose dorsolateral setae with two pairs of lancelike dorsomedian setae that are narrowly spaced, the first situated just behind the posterior pair of dorso- laterals, the second behind the first and the end of the shield; hysterosomal shields irregularly ovate, with one pair of lance-like pilose setae located near the lateral margins.

Seven additional pairs of dorsals are located on small platelets, the median platelet is the larger.The ventral surface exhibits the usual six pairs of ventral setae. All three pairs of anal setae are hair-like but the posterior pair is somewhat thickened. Leg setation is normal for the family. The long curved solenidion of tarsus I is located on a distinct cylindrical tubercle with closely associated guard setae; the terminal sensory setae are as the segment. The tursus is 2.5 times the length of the tibia Palpal femur as wide as long, with dorsal setae fan-like and two hair-like ventral setae; dorsal genual setae fan-like, the lateroventral setae clavate; setation of tibia and tarsus normal; tibial claw with 7 teeth.

\section{Types locacality:}

Holotype: Adult female collected from apple, Malus sp.( Rosaceae) in Beer ElAbd, North Sinai, Egypt.

Paratypes: Several adult females with the same data of holotype, and on grape, Vitisvinifera (Vitaceae), figs, Ficuscarica.

(Moraceae), date palm, Pheonixdactylifera (Palmaceae) and on pomegranate Punicagranatum (Punicaceae) in El-Arish, North Sinai, Egypt.
Allotype:
Male, not captured. 


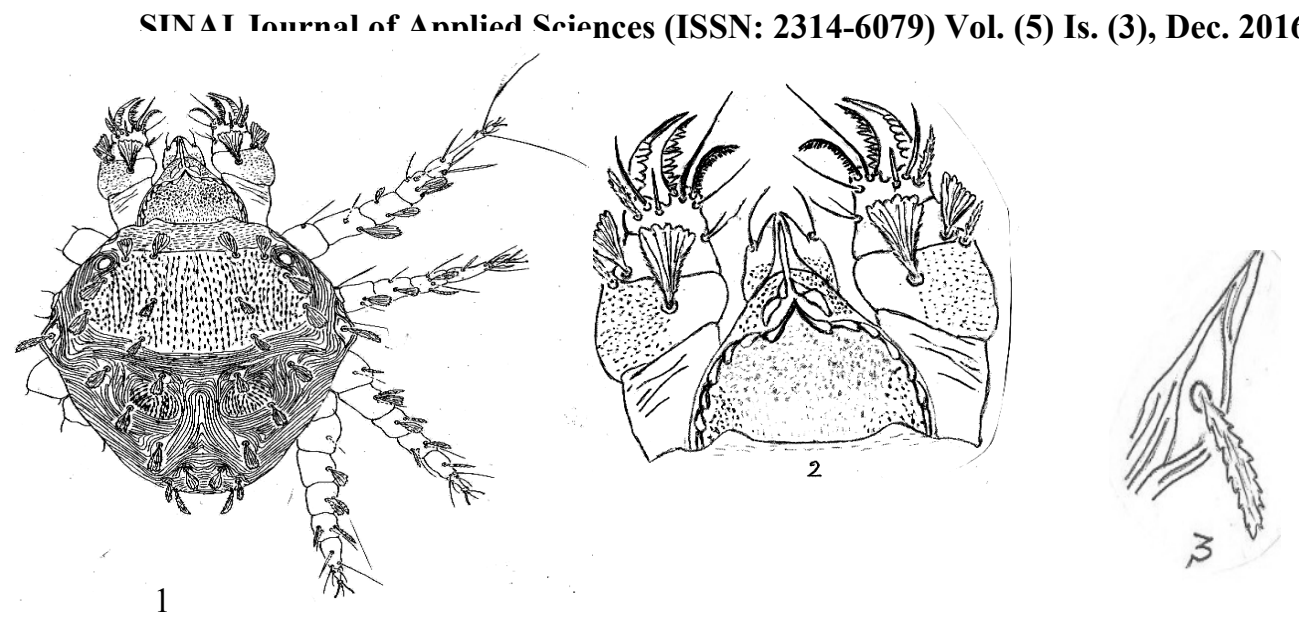

Figs. (1-3): Cheletomimussinaii n. sp.
(1) Dorsal aspect of female,
(2) Gnathosoma,
(3) Humeral setae.

\section{Elymology:}

The name of this species is associated with the collecting site (Sinai peninsula, Egypt).

\section{Genus Paralorryia Baker}

\section{Paralorryia, Baker, 1965:104.}

Diagnosis: The body shape and relative leg sizes are, in general, similar to those species of the genus LorryiaOudemans, and $\mathbf{1 9 6 8}^{\mathrm{a}}$ Ann. ent. Soc. Amer., 61: 986.

\section{Paralorryiaegyptocitri n. sp. Figs. (4-7)}

(in the past several of these species have been assigned to that genus. The $\mathrm{L}_{2}$ setae are in the lateral position, and there are four and one-half rows of hysterosomal setae; Setae $\mathrm{L}_{5}$ aremissing. The body may be entirely covered with striae, or may possess some reticulated areas; the striaeare longitudinal between setae $\mathrm{D}_{2}$; the lobes are usually low and broad, or rounded. There are six pairs of genital setae, four pairs of paragenital setae, one pair of anal setae and three pairs of ventral setae. The palpalsetal pattern is 5-2-2; the palpal tarsus is usually long and slender. The setal pattern of leg 1 appears to be constant, but the pattern of the other legs may vary on a few species. The typical generic leg setal pattern is: (I) 8-33-3-1-2; (II) 6-2-2-3-0-1; (III) 5-2-1-2-1-3; (IV) $5-2-1-1-0-1$.

\section{Type species}

LorryiacumbrensisBaker 1968 $^{\mathrm{a}}$ Ann. ent. Soc. Amer.,61:986.

\section{Paralorryiaegyptocitri n. sp.Figs. (4-7)}

This species is similar to Paralorryiazaheri Baker in most characters except the longitudinal striae of hysterosoma which start from setae $D_{1}$ posteriorly to include setae $\mathrm{D}_{3}$ and laterally to include setae $\mathrm{L}_{2}$ and $\mathrm{L}_{3}$ in P.zaheri, while in the new species it extends from setae $\mathrm{D}_{1}$ to alveoliof setae $\mathrm{D}_{2}$. Dorsal body setae (except the sensory setae) being short, lanceolate, finely serrate and subequal in length in P. zaheri, while they are longer in the new species.

FEMALE: Gnathosoma covered partly by propodosoma, palpus completely visible from above, movable chelae slightly longer than the distal segment of palpus, palpus elongate, terminal setae expanded distally. Propodosomal sensory setae slender, whiplike, not as long as other dorsal body setae; setae $\mathrm{P}_{3}$ longer than the subequal setae $\mathrm{P}_{1}$ and $\mathrm{P}_{2}$. 


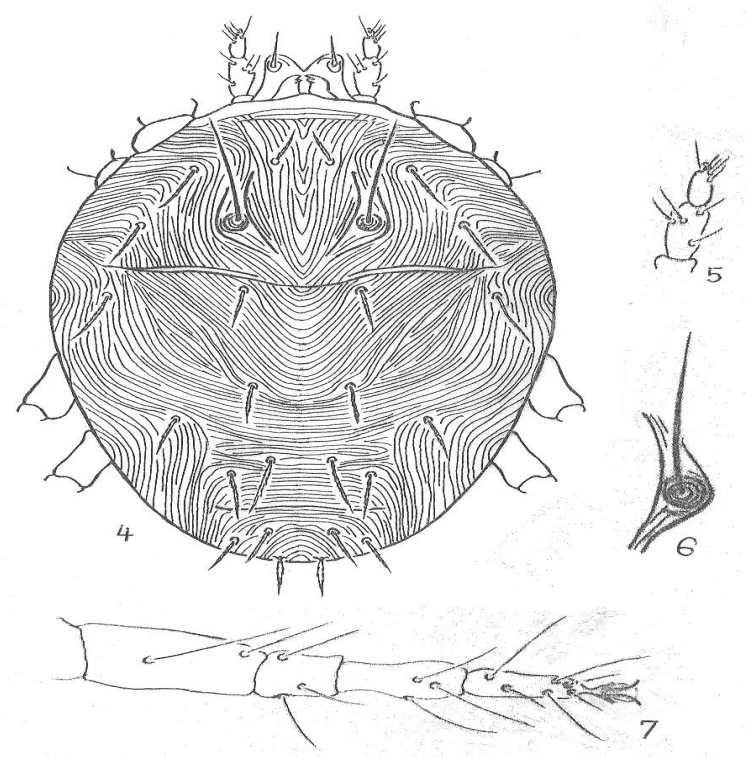

Figs. (4-7): Paralorryiaegyptocitri n. sp.
(4) Dorsal aspect of female.
(5) Palp.
(6) Sensory seta.
(7) Leg 1.

All dorsal bodysetae sharp distally, slightly serrate. Setae $\mathrm{P}_{1}, \mathrm{D}_{1}, \mathrm{D}_{2}, \mathrm{D}_{4}, \mathrm{~L}_{2}$ and $\mathrm{L}_{4}$ subequal in length and slightly shorter than the subequal setae $\mathrm{P}_{2}, \mathrm{P}_{3}, \mathrm{D}_{3}, \mathrm{~L}_{1}$ and $\mathrm{L}_{3}$; setae $\mathrm{L}_{5}$ seem to be the shortest, originate on obvious tubercle. Striae longitudinal on propodosomalmediam part, being transverse laterally; hysteron-soma with the longitudinal striae extend from setae $D_{1}$ to aloveoli of setae $D_{2}$, being irregular from setae $\mathrm{L}_{1}$ to $\mathrm{L}_{4}$ and transverse from setae $D_{3}$ to setae $D_{5}$.Ventrum with three pairs of setae, six pairs of genitals, four pairs of paragenitals and one pair of annals. Empodia with claws. Length of body $259 \mu$; width $148 \mu$.

MALE: Not captured.

Holotype: Adult female collected from sweet orange, Citrus sinensisOsbeck in Beer El- Abd, North Sinai, Egypt. Paratypes: Several adult females with the same data of paratype and on mulberries, Morus spp. in Beer El- Abd and El-Arish; Guava, Psidiumguajava in Beer El- Abd and on sweet orange and olive, Oleaeuropaea L. in El-Arish.
Allotype: Male not captured.

Elymology: The name of this species is associated with the collected site (Egypt) and the attacked host (C. sinensis).

\section{CONCLUSIONS}

Two new species of mites, Cheletomimussinaiin. sp. (Acari, Prostigmata: Cheyletidae) and Paralorryiaegyptocitri n. sp. (Acari, Prostigmata: Tydeidae) are illustrated and described. They inhabit some fruit trees in North Sinai, Egypt.

\section{REFERENCES}

Baker, E.W. (1965). A review of the genera of the family Tydeidae. In J.A. Naegele [ed.]. Advances inAcarology, vol. 2, Cornell Univ. Press, Ithaca, N.Y.:95-133.

Baker, E.W. (1968 $\left.{ }^{\mathbf{a}}\right)$. The genus Lorryia. Ann. ent. Soc. Amer., 61:986-1008.

Baker, E.W. $\left(\mathbf{1 9 6 8}^{\mathbf{b}}\right)$. The genus Paralorryia . Ann. ent. Soc. Amer., 61(5): 1097-1106. 
Gerson, V.(1968). Five tydeid mites from Israel (Acarina: Prostigmata). Israel J. Zool., 17(4):191-198. (Published online: 30 Abril 2013).

Hessein, N.A. and T.M. Perring (1986). Feeding habits of the Tydeidae with evidence of Homeoprone- matusanconai (Acai: Tydeidae) predation of Aculoppslycopersici (Acari: Eriophyidae). Int. J. Acarol., 12:215-222.

Marshall, V.G. (1970). Tydeid mites (Acarina: Prostigmata) from Canad. 1. New and described species of lorryia. Ann. Soc. Entomol. Que., 15:17-52.

Momen, F.M. (1986). Mites associated with unsprayed orchards with particular refere-nce to trophic relationships and feeding mecha- nisms. Ph.D. Thesis, University College Dublin, Irland.

Muma, M.H. (1964). Cheyletidae (Acarina: Trombidiformes) asso-ciated with citrus in Florida. The Florida Entomologist, 47(4): 239-253.

Negm, M.W. and A.E. Mesbah (2014). Review of the mite family Cheyletidae (Acari, Trombidi-formes, Cheyletoidea) of Egypt. Internat. J. Acarol. 40, 5: 390396.

Oudemans, A.G. (1904a). Acarologische Anateekeningen. XI. Ent. Ber. Nederl.
Ent. Ver. 1(17):154. [cited from Summers and Price, 1970].

Oudemans, A.G. $\left(\mathbf{1 9 0 4}^{\text {b }}\right)$. Acarologische Anateekeningen. XI1. Ent. Ber. Nederl. Ent. Ver. 1(18): 160-163. [cited from Summers and Price, 1970].

Rasmy, A.H. and M.E. El-Bagoury (1980). New species of genus Paralorryia from Egypt (Acarina: Tydeidae). Acarologia, 21(2): 194-196.

Soliman, Z.R. (1975). Threenewspecies ofcheyletid mitesfrom Egypt (Acari: Prostigmata) with a key to genera. Acarologia, 17: 95-102.

Summers, F.M. and D.W. Price (1970). Review of the mite family Cheyletidae. University of California Press, Berkeley, Los Angeles, London, 153 pp.

Yunker Conrad, E. (1961). The genus Bak, new genus, and Cheletomimus Oudemans with description of three new species. Canadian Ent., 93(11): 1023-1035.

Zaher, M.A. and M.E. El-Bagoury (1981): A new tydeid mite, Paralorryiabakeri n. sp. From Egypt (Prostigmata: Tydeidae). Acarologia, 22: 179-180. 


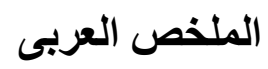

نوعان جليدان من الفونـا الأكاروسية التي تقطن بعض أشجار الفاكهة في شمال سيناء، مصر

(Acari: Cheyletidae\&Tydeidae)

إيمان عبد الله إبراهيم على'، محمد محمد حسن قنديل ، صلاح محمد عبد الكريم'، ومحمد نجيب البسيونى'

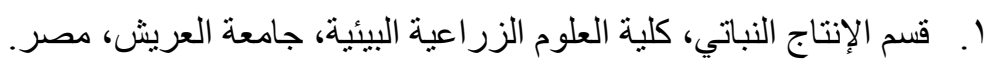

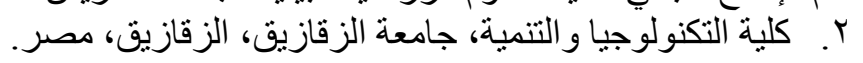

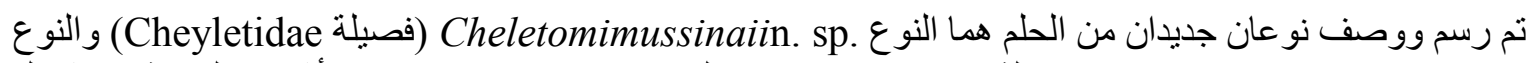

Paralorryiaegyptocitri n. sp. سيناء - مصر.

الكلمات الاسترشادية: توصيف، أصناف جديدة. 